\title{
Lymphtoxin $\beta$ Receptor-Ig Protects from T-Cell-Mediated Liver Injury in Mice through Blocking LIGHT/HVEM Signaling
}

\author{
Mao-Mao AN, ${ }^{a, \#}$ Ke-Xing Fan, ${ }^{b, \#}$ Yong-Bing CAO,${ }^{a}$ Hui SHEN,${ }^{a}$ Jun-Dong Zhang, ${ }^{a}$ Lei Lu, ${ }^{c}$ \\ Ping-Hui GAO, ${ }^{a}$ and Yuan-Ying JIANG ${ }^{*, a}$ \\ ${ }^{a}$ Department of Pharmacology, College of Pharmacy, Second Military Medical University; 325 Guo He Road, Shanghai \\ 200433, P.R. China: ${ }^{b}$ International Joint Cancer Institute, Second Military Medical University; 800 Xiang Yin Road, \\ Shanghai 200433, P.R. China: and ${ }^{c}$ Department of Pharmaceutics, College of Pharmacy, Second Military Medical \\ University; 325 Guo He Road, Shanghai 200433, P.R. China. Received March 26, 2006; accepted June 20, 2006
}

LIGHT is a member of the TNF superfamily, which is transiently expressed on the surface of activated T lymphocytes and immature dendritic cells. Its known receptors are herpesvirus entry mediator (HVEM) prominently in T lymphocytes, and lymphtoxin $\beta$ receptor $(\mathrm{LT} \beta R)$ in stromal cells or nonlymphoid hematopoietic cells.Previous studies have shown that overexpression of LIGHT on T cells could lead to autoimmune reaction including lymphocytes activation, inflammation, and tissue destruction. To address the role of LIGHT/HVEM signaling in autoimmune hepatitis, an experimental colitis model induced by intravenous administration of concanavalin A (ConA) was given a soluble LT $\beta$ R-Ig fusion protein as a competitive inhibitor of LIGHT/HVEM pathway. Marked elevation of LIGHT expression was detected in isolate intrahepatic leukocytes (IHLs) of the experimental animal. Treatment with LT $\beta$ R-Ig significantly attenuated the progression and histological manifestations of the hepatic inflammation and reduced the production of inflammatory cytokines including TNF- $\alpha$, IFN$\gamma$. Moreover, LT $\beta$ R-Ig treatment significantly down-regulated LIGHT expression, leading to reduced lymphocytes (particularly $\mathrm{CD}^{+} \mathrm{T}$ cells), infiltrating into the hepatic inflammation and inhibited $\mathrm{NF}-\mathrm{KB}$ activation and expression. We postulated that blockade of LIGHT/HVEM signaling by LT $\beta$ R-Ig may ameliorate hepatitis by down-regulating LIGHT expression, and therefore we envision that LT $\beta$ R-Ig would prove to a promising strategy for the clinical treatment of human autoimmune hepatitis.

Key words $\quad$ LT $\beta$ R-Ig; LIGHT; ConA-induced hepatitis

LIGHT, a TNF superfamily member, is mainly expressed on the surface of activated $\mathrm{T}$ lymphocytes and immature dendritic cells. ${ }^{1,2)}$ It can bind specifically to two ligands: Lymphotoxin $\beta$ receptor (LT $\beta \mathrm{R}$ ), a member of the TNF receptor family, which is expressed on stromal cells or nonlymphoid hematopoietic cells, and herpesvirus entry mediator (HVEM) which is expressed prominently on T lymphocytes. LIGHT is a potent $\mathrm{T}$ cell costimulatory molecule that appears to interact with the HVEM. ${ }^{1,3,4)}$ But unlike most other costimulatory molecules delivering signals from angtigen presentation cells (APCs), overexpression of LIGHT on T cells lead to lymphocytes activation, inflammation and tissue destruction ${ }^{5-7)}$ and LIGHT/HVEM signaling is believed to participate in T-T cell interaction resulting in $\mathrm{T}$ cells activation and expansion, and promote the development of $\mathrm{T}$ cell-associated autoimmune diseases. Blockade of LIGHT activation ameliorated the severity of $\mathrm{T}$ cell-mediated disease such as insulin-dependent diabetes mellitus (IDDM) and inflammatory bowel disease (IBD). ${ }^{6,8)}$

$\mathrm{T}$ cell-mediated immune responses play important roles in the pathogenesis of a variety of human liver disorders, ${ }^{9-11)}$ including autoimmune liver disease, ${ }^{12)}$ viral hepatitis, ${ }^{13,14}$ and alcoholic liver disease. ${ }^{15)} \mathrm{T}$ cell-mediated hepatitis can be induced in rodents by injection of the $\mathrm{T}$ cell mitogenic plant lectin concanavalin A (ConA), which rapidly induces clinical and histological evidence including elevation of transaminase activities, T-cell infiltration, apoptosis and necrosis in liver within $8-24 \mathrm{~h}^{16)}$ ConA induced hepatitis dependent on T-cell activation is limited to the liver, as indicated by nonoccurrence in athymic nude mice, SCID mice, $\mathrm{BALB} / \mathrm{c}$, and FK506-pretreated mice. ${ }^{16,17)}$ Intravenous ad- ministration of ConA induces lymphocyte accumulation in the liver through the increased influx of circulating lymphocytes and local proliferation via blastoid formation. ${ }^{18)} \mathrm{T}$ cell especially $\mathrm{CD}^{+} \mathrm{T}$ cell activation elicited by ConA results in the elevation of the plasma levels of various proinflammatory cytokines including tumor necrosis factor alpha (TNF- $\alpha$ ), interferon gamma (IFN- $\gamma$ ), and interleukin (IL), and these proinflammatory cytokines contribute to the development of hepatitis. ${ }^{18)}$ In particular, TNF- $\alpha$ and IFN- $\gamma$ released from activated $\mathrm{CD} 4^{+} \mathrm{T}$ cells are considered to play critical roles in the development of ConA-induced hepatic injury because passive immunization against these cytokines effectively protects animals from hepatic injury. ${ }^{18-21)}$ Activation of LIGHT/HVEM signaling leading to T cell activation and expansion, together with the important role of $\mathrm{T}$ cell activation and infiltration in the ConA induced hepatitis, suggest a role for LIGHT signaling in the ConA induced hepatitis and used LT $\beta$ R-Ig to block LIGHT signaling may ameliorates this disease.

The nuclear factor $\kappa \mathrm{B}(\mathrm{NF}-\kappa \mathrm{B})$ complex could regulate host inflammatory and immune responses by increasing the expression of many cytokines including TNF- $\alpha$, IFN- $\gamma$ and IL. ${ }^{22)}$ It is involved in upregulating the expression proinflammatory cytokines in ConA induced hepatitis and inhibition of NF- $\kappa \mathrm{B}$ could attenuate this disease. ${ }^{23)}$ Activation of LIGHT/HVEM signaling also induced marked activation of $\mathrm{NF}-\kappa \mathrm{B}{ }^{24)}$ So in this study we further tested the effect of LT $\beta$ R-Ig treatment on the expression of NF- $\kappa$ B.

The present study described the protective effect of LT $\beta$ RIg in the ConA-induced liver injury in vivo and examined the possible mechanism of LT $\beta$ R-Ig regarding liver injury. Our 
results suggested a role for LIGHT/HVEM signaling in the development and/or progression of experimental hepatitis.

\section{MATERIALS AND METHODS}

Experimental Animals Specific pathogen free male BALB/c mice were obtained from the Experimental Animal Department of Fu Dan University (Shanghai, China). The mice were fed with a standard laboratory diet and given free access to tap water, kept in a room with controlled temperature $\left(22 \pm 1^{\circ} \mathrm{C}\right)$, humidity $(65-70 \%)$, and a $12: 12$-h light : dark cycle. All animals received humane care in compliance with the institutional animal care guidelines, and were approved by the Local Institutional Committee.

Test Substance The cDNA encoding the extracellular domain of murine LT $\beta \mathrm{R}$ was fused with the Fc portion of human $\operatorname{IgG1}$, and then inserted intopcDNA3.1 (+). Stable transfectants expressing the $\mathrm{mLT} \beta \mathrm{R}-\mathrm{Fc}$ fusion protein were prepared by transfecting of Chinese Hamster Ovary (CHO) cells with the corresponding expression construct using Lipofectamine $^{\mathrm{TM}} 2000$ (Invitrogen), following the manufacturer's instructions. Transfected cells were selected and maintained in G418 $\left(0.8 \mathrm{mg} \mathrm{ml}^{-1}\right)$. The murine LT $\beta \mathrm{R}-\mathrm{Ig}$ in culture supernatants of $\mathrm{CHO}$ cells was purified on a protein A column. Purified human IgG (Sigma) was used as control.

ConA-Induced Hepatic Injury and Treatment Schedules ConA $(20 \mathrm{mg} / \mathrm{kg})$ (Sigma) was administered intravenously to $\mathrm{BALB} / \mathrm{c}$ mice, but animals in normal control group was injection equal normal saline instead. LT $\beta \mathrm{R}-\mathrm{Ig}$ or control human IgG was administered intraperitoneally $200 \mu \mathrm{g} 12 \mathrm{~h}$ before and after immediately ConA injection. Blood samples were collected at the indicated time points and the animals were sacrificed $24 \mathrm{~h}$ after the ConA injection, at the same time livers were collected.

Determination of Liver Injury Liver injury was determined by H\&E staining, TUNEL (Terminal Deoxynucleotidyl Transferase-Mediated dUTP Nick End Labeling) staining of histological sections and measuring alanine aminotransaminase (ALT) and aspartate aminotransferase (AST) activities. For H\&E staining, the samples of livers were fixated in $10 \%$ formalin, then sliced into $4-6 \mathrm{~mm}$ pieces, dehydrated in ethanol, embedded in paraffin wax, sectioned $(4 \mu \mathrm{m})$, and stained with hematoxylin and eosin. Cells undergoing apoptosis were detected using a modified TUNEL method with commercial kit (R\&D) according to the manufacturer's instructions. ALT and AST activities were measured before and at 5,12 and $24 \mathrm{~h}$ after the ConA injection using a kit purchased from Sigma.

Measurement of Plasma Pro-inflammatory Cytokines Blood was sampled from experimental animals before and at $0,1.5,5$ and $12 \mathrm{~h}$ after the ConA injection, then the serum was separated by centrifugation at $3000 \mathrm{rpm}$ for $15 \mathrm{~min}$. Using serum at each time point, the Plasma pro-inflammatory Cytokines was quantified with commercial mice TNF- $\alpha$, IFN- $\gamma$ ELISA kits (Biosource) according to the manufacturer's instructions. The final value of cytokine concentration was represented as $\mathrm{pg} \mathrm{ml}^{-1}$.

Flow Cytometry Analysis on LIGHT Expression Isolate intrahepatic leukocytes (IHLs) were prepared according with the method described previously. ${ }^{23)}$ Total IHLs were digested with RPMI 1640 (Life Technologies) containing
$0.02 \%$ collagen's IV (Sigma-Aldrich) and $0.002 \%$ Dnase I (Sigma-Aldrich) for $40 \mathrm{~min}$ at $37^{\circ} \mathrm{C}$. Cells were washed with RPMI 1640 and then underlaid with 24\% metrizamide (Sigma-Aldrich) in PBS. After centrifugation for $20 \mathrm{~min}$ at $1500 \boldsymbol{g}$, IHLs were isolated at the interface. T cells were purified via negative selection using a $\mathrm{T}$ cell isolation kit (Miltenyi Biotec) according to the manufacturer's directions.

Single-cell suspension of IHLs was washed in PBS containing $1 \%$ bovine serum albumin and $0.02 \%$ sodium azide, and then incubated for 20 min on ice to block FcR. The cells were indirectly stained for LIGHT expression on IHLs using a rat anti-mouse Mab (R\&D), and detected after washing by a FITC-conjugated goat anti-rat IgG (AbD Serotec) for 30 min on ice per step. Anti-human IgG Fc (Sigma-Aldrich) was used to detect LT $\beta$ R-Ig binding to IHLs. Isotypes controls were used for detecting nonspecific staining in this test. Samples were acquired on a FACS Calibur flow cytometer and the data were analyzed using CellQuest software (BD Immunocytometry Systems).

Immunofluorescent Analysis on $\mathrm{CD4}^{+}$Lymphocyte Immunofluorescent staining and confocal laser imaging Cryostat sections were performed at $10 \mathrm{~mm}$, fixed in acetone/ methanol $(1: 1)$ at $4{ }^{\circ} \mathrm{C}$ for $10 \mathrm{~min}$. After washing in PBS, slides were blocked with PBS containing 3\% BSA and then incubated overnight with the anti-CD4 Ab (PharMingen), at $4^{\circ} \mathrm{C}$ in a moist, light-protected chamber. After rinsing with PBS, binding sites was detected with the secondary Ab (goat anti-rat IgG tagged with Texas Red, Dianova) dissolved in PBS/BSA 3\% for $1 \mathrm{~h}$ at room temperature. After washing in PBS, slides were mounted with TBS/glycerol $(1: 1)$, pH 8.6. Sections were then examined by confocal laser scanning microscopy (Bio-Rad 1000).

Western Blot and Electrophoretic Mobility Shift Assay (EMSA) Analysis for NF- $\boldsymbol{k B}$ Nuclear proteins were isolated from liver tissues at $5 \mathrm{~h}$ after LT $\beta \mathrm{R}$-Ig treatment as described previously. ${ }^{25}$ ) Nuclear extracts were separated on a $10 \%$ SDS-polyacrylamide gel and blotted onto a nitrocellulose membrane in $1 \% \mathrm{SDS}, 20 \%$ methanol, $400 \mathrm{~mm}$ glycine, $50 \mathrm{~mm}$ Tris- $\mathrm{HCl}(\mathrm{pH} 8.3)$, at $4{ }^{\circ} \mathrm{C}$ for $2 \mathrm{~h}$ at $200 \mathrm{~mA}$. Western blot analysis was performed. Membranes were probed with anti-NF- $\kappa \mathrm{B}$ p65 Abs (Santa Cruz). The Ag-Ab complexes were visualized using the ECL detection system as recommended by the manufacturer (Amersham). Western blot analysis was performed for each protein of interest at least three times.

EMSA was performed using gel shift assay system from Promega (Madison, WI, U.S.A.) according to the manufacturer's directions by using $\left[{ }^{32} \mathrm{P}\right]$. Subsequent to electrophoresis by using $5 \%$ non-denaturing polyacrylamide gels at room temperature, gels were dried and exposed to X-Omat film (Eastman Kodak, Rochester, NY, U.S.A.) for autoradiography. Cold competition step in EMSA confirmed that the band observed on the gel was NF- $\kappa \mathrm{B}$. Blots were scanned using a GS-800 imaging densitometer (BioRad).

Statistical Analysis The data were expressed as mean \pm standard deviation (S.D.). For statistical analysis the ANOVA was used. $p<0.05$ was considered to be statistically significant. 


\section{RESULT}

LT $\beta$ R-Ig Protects against ConA-Induced Liver Injury in Mice To determine the effect of LT $\beta \mathrm{R}-\mathrm{Ig}$ on ConA induced hepatitis, LT $\beta$ R-Ig fusion protein $(200 \mu \mathrm{g})$ was administrated to block all LT $\beta$ R-Ig related signaling pathway $12 \mathrm{~h}$ before and after immediately ConA $(20 \mathrm{mg} / \mathrm{kg})$ injection to $\mathrm{BALB} / \mathrm{c}$ mice. After ConA injection, serum aminotransferase levels rose significantly within $5 \mathrm{~h}$, and remained elevated until $24 \mathrm{~h}$ and treatment with LT $\beta \mathrm{R}-\mathrm{Ig}$ significantly reduced serum alanine aminotransferase activation (Figs. 1A, B).

Microscopic examination of liver sections from animals administered with ConA alone revealed severe morphological changes which are characteristic of apoptosis (Fig. 2D) and massive necrosis (Fig. 2B), while administrated with LT $\beta$ R-Ig and ConA only focal necrosis (Fig. 2C) and apoptosis observed (Fig. 2E). We also quantified hepatotoxicity by counting cells positive for TUNEL, and marked decrease of the number of cell deaths was observed in the livers of mice treated with LT $\beta$ R-Ig compared with those of mice treated with control human IgG (Fig. 2F).

Effect of LT $\beta$ R-Ig on TNF- $\alpha$ and IFN- $\gamma$ in Plasma Level Since TNF- $\alpha$ and IFN- $\gamma$ are known to play an essential role in ConA induced hepatitis, ${ }^{18-21)}$ we then examined whether or not TNF- $\alpha$ and IFN- $\gamma$ production is affected in ConA induced hepatitis. TNF- $\alpha$ and IFN- $\gamma$ plasma levels were determined in ConA-treated mice with or without administration of LT $\beta$ R-Ig. The plasma TNF- $\alpha$ and IFN- $\gamma$ levels increased upon ConA injection and reached maxima at $1.5 \mathrm{~h}$, administration of LT $\beta \mathrm{R}-\mathrm{Ig}$ significantly suppressed plasma TNF- $\alpha$ and IFN- $\gamma$ levels in mice of ConA induced hepatitis compared to human IgG treatment (Figs. 3A, B).

LT $\beta$ R-Ig Attenuates CD4 ${ }^{+}$T Lymphocytes Infiltration and NF- $\kappa$ B Activation, Overexpression in ConA-Induced Liver Injury The above results indicated that LT $\beta$ R-Ig may protect mice from ConA-induced hepatitis through inhibition of pro-inflammatory cytokines production, such as TNF- $\alpha$ and IFN- $\gamma$. CD4 ${ }^{+}$T cells were essential for the elevated cytokine production responsed to ConA injection. To investigate whether mononuclear cells infiltrating the liver represent $\mathrm{CD}^{+} \mathrm{T}$ cells, we performed immunofluorescent analysis the liver of $24 \mathrm{~h}$ after ConA injection. In mice with hepatitis treatment by human IgG a large number of cells are stained with anti-CD4 $4^{+} \mathrm{mAb}$ while only weak $\mathrm{CD} 4^{+}$staining was observed in normal control mice (Figs. 4A, B). There
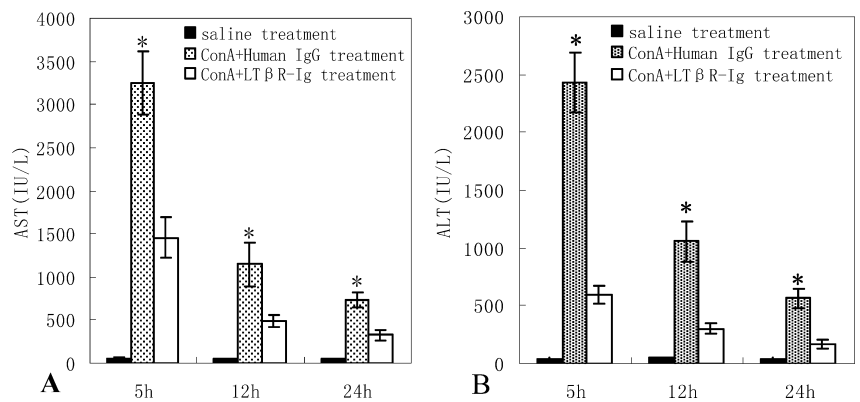

Fig. 1. LT $\beta$ R-Ig Protected from ConA Inudced Hepatitis

$\mathrm{BALB} / \mathrm{c}$ mice were injected with $20 \mathrm{mg} / \mathrm{kg}$ ConA in the presents or absence LT $\beta \mathrm{R}-\mathrm{Ig}$ treatment. Blood samples were collected as indicated time points and serum (A) alanine aminotransferase, (B) aspartate aminotransferase activities were determined as indices of hepatotoxicity. Data were the mean \pm S.D. of 10 mice. $* p<0.05$ compared with mice treated with Human IgG and saline treatment. was a markedly decrease in $\mathrm{CD} 4^{+} \mathrm{T}$ cells infiltration in the liver of LT $\beta$ R-Ig treatment mice compared with that in the liver of human IgG treatment (Figs. 4B, C).

TNF- $\alpha$ and IFN- $\gamma$ gene expression can be regulated by transcription factors, including NF- $\kappa \mathrm{B}$ and activator protein
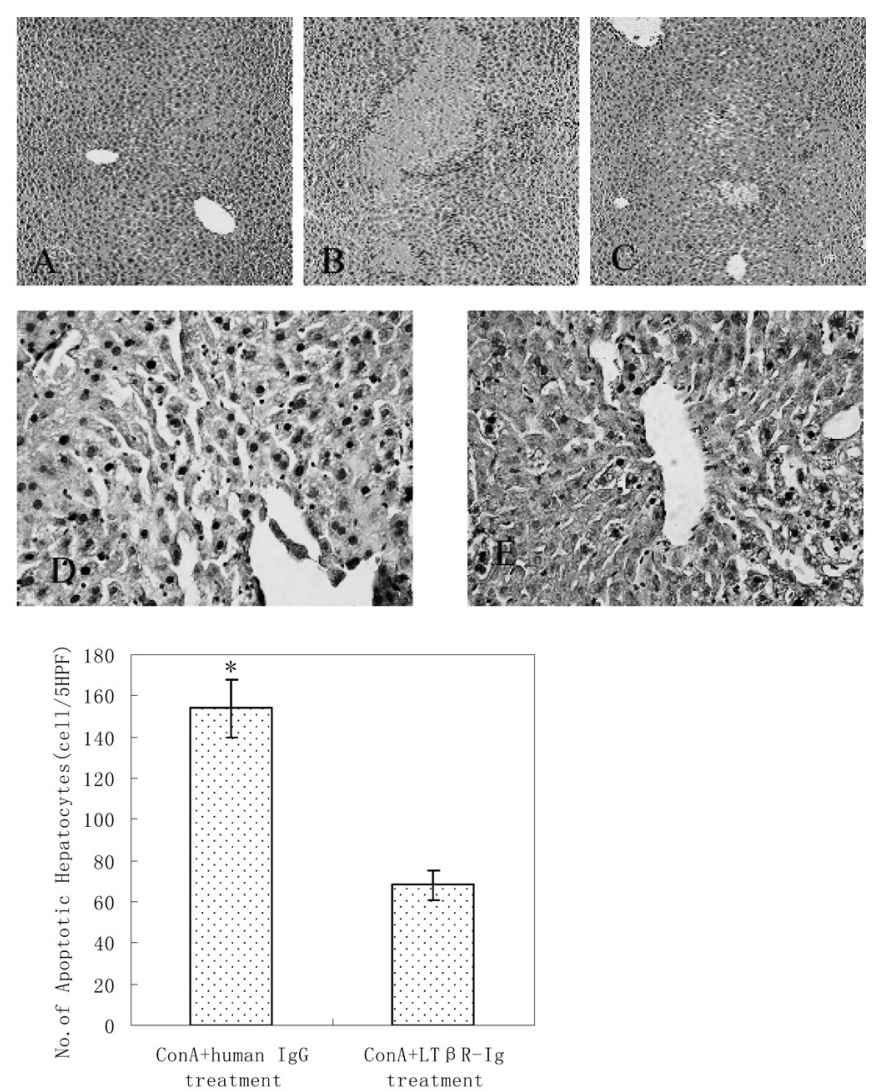

Fig. 2. Histological Analyses of Livers from (A) Mice $24 \mathrm{~h}$ after Saline Injection, (B) Mice $24 \mathrm{~h}$ after ConA Injection with Human IgG Treatment, (C) Mice $24 \mathrm{~h}$ after ConA Injection with LT $\beta$ R-Ig Treatment (HE Staining, $n=10)$ and Induction of Apoptosis in the Livers of (D) Mice $24 \mathrm{~h}$ after ConA Injection with Human IgG Treatment, (E) Mice $24 \mathrm{~h}$ after ConA Injection with LT $\beta$ R-Ig Treatment (TUNEL, $n=10$ )

(F) Apoptotic Hepatocytes Were Counted and Averaged for Five Randomly Chosen High-Power Fields $(\mathrm{HPF} \times 200)$

The necrosis and apoptosis induced by ConA in the liver was significantly suppressed after LT $\beta$ R-Ig treatment. Data were the mean \pm S.D. of 10 mice. $* p<0.05$ compared with mice treated with ConA + Human IgG treatment.
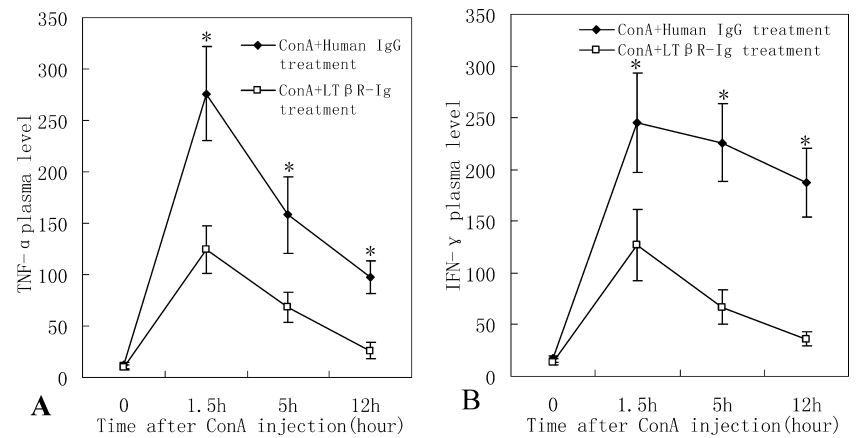

Fig. 3. ConA Induced Plasma Levels of (A) TNF- $\alpha$, (B) IFN- $\gamma$ Increasing and LT $\beta$ R-Ig Prevent TNF- $\alpha$ and IFN- $\gamma$ Release

Animal were sacrificed and blood samples were collected as indicated time points after ConA injection. TNF- $\alpha$, IFN- $\gamma$ levels were assayed by ELISA and data were the mean \pm S.D. of 10 mice. $* p<0.05$ compared with mice treated with Human IgG. 

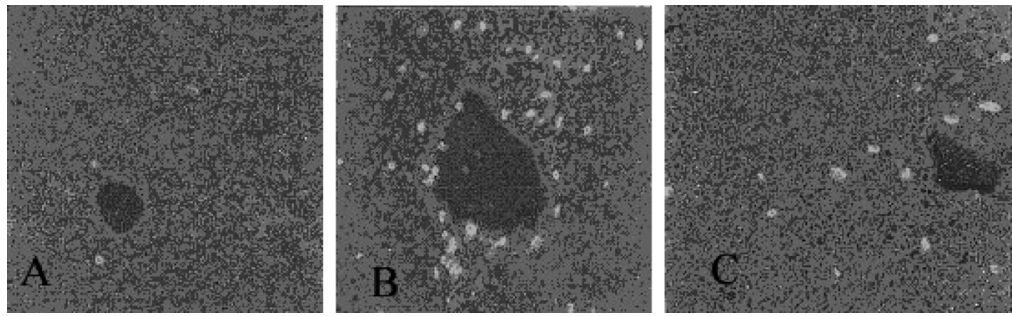

Fig. 4. Representative Image of Immunohistochemical Analysis on $\mathrm{CD} 4^{+}$Lymphocytes in Liver Tissue of Mice after $24 \mathrm{~h}$ ConA Injection $(n=10)$

(A) Saline treatment group. (B) ConA+Human IgG treatment. (C) ConA $+\mathrm{LT} \beta \mathrm{R}$-Ig treatment. The number of $\mathrm{CD}^{+} \mathrm{T}$ cells in the liver tissue of hepatitis mice markedly decreased, comparing with that in those treated with human IgG.

A.

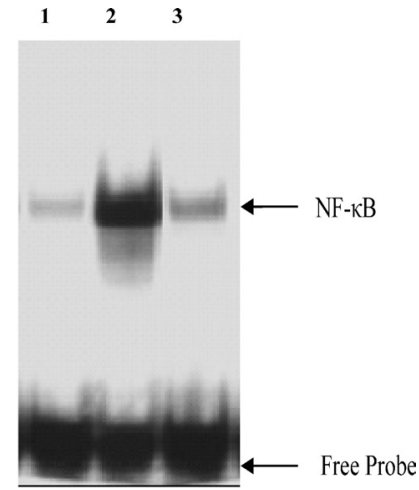

B.

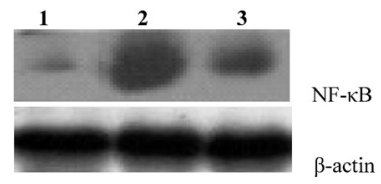

Fig. 5. NF- $\kappa \mathrm{B}$ Activation and Expression in the Liver of Mice after $24 \mathrm{~h}$ Injection of ConA

(A) NF- $\kappa$ B DNA binding activity in the presence or absence of LT $\beta$ R-Ig treatment via electrophoretic mobility shift assay using liver nuclear extracts. Induction of NF- $\kappa \mathrm{B}$ activity in the liver was inhibited by LT $\beta$ R-Ig. Lane 1: saline treatment. Lane 2 : ConA + Human IgG treatment. Lane 3: ConA + LT $\beta$ R-Ig treatment. (B) NF- $\kappa$ B expression in the presence or absence of LT $\beta$ R-Ig treatment. Lane 1: saline treatment. Lane 2 ConA + Human IgG treatment. Lane 3: ConA + LT $\beta$ R-Ig treatment. Induced NF- $\kappa$ B overexpression by ConA in the liver of mice was inhibited after LT $\beta$ R-Ig treatment

1. It has been well demonstrated that activation of LIGHT/HVEM signaling induced marked activation of NF$\kappa \mathrm{B}^{24)}$ To elucidate the mechanism by which LT $\beta$ R-Ig protected mice from ConA-induced hepatitis, we investigated whether NF-kB was regulated by LT $\beta$ R-Ig. EMSA and Western blot analysis demonstrated induction of NF- $\kappa \mathrm{B}$ activity and overexpression by stimulation of ConA in the liver; treatment with LT $\beta$ R-Ig resulted in a marked decrease of the induction of NF- $\kappa \mathrm{B}$ activity and expression in the liver (Figs. $5 \mathrm{~A}, \mathrm{~B})$.

LT $\beta$ R-Ig Could Bind to LIGHT on IHL Cells in the Liver and Downregulated its Expression Mice expressing the LIGHT transgene on the $\mathrm{T}$ cell lineage exhibited severe $\mathrm{T}$ cell-mediated inflammation and autoimmune disease. ${ }^{6)}$ Blockade of LIGHT by HVEM-Ig reduced T cell proliferation and the incidences of T cell-mediated diseses. ${ }^{7)}$ In the present study when IHLs from the liver of mice stimulated by ConA was incubated with LT $\beta$ R-Ig for $45 \mathrm{~min}$, the level of LT $\beta$ R-Ig binding to IHLs pretreated with antiLIGHT mAb was markedly decreased compared with that without anti-LIGHT mAb pretreatment (Fig. 6), indicating specific binding of LT $\beta$ R-Ig to LIGHT on IHLs. So the ef-
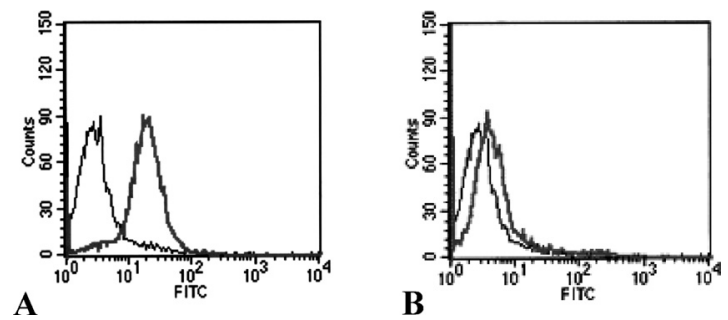

Fig. 6. Representative Image of FACS Analysis on the Level of LT $\beta$ R-Ig Binding to IHLs from the Liver of Mice after $24 \mathrm{~h}$ ConA Injection $(n=10)$

(A) IHLs incubated with LT $\beta$ R-Ig. (B) IHLs pretreated by anti-LIGHT mAb incubated with LT $\beta$ R-Ig. After incubated for $45 \mathrm{~min}$, the level of LT $\beta$ R-Ig binding to IHLs pretreated by anti-LIGHT mAb was markedly decreased, compared with that without anti-LIGHT mAb pretreatment.

fect inhibition T cell infiltration in the live of LT $\beta$ R-Ig might be mostly attributed to blockade of LIGHT/HVEM signaling. To test this possibility, we used Flow Cytometry to measure the expression of LIGHT on IHLs. The results demonstrated induction of LIGHT overexpression on IHLs by stimulation of ConA in the liver; Compared to human IgG treatment, the level of LIGHT expression on the IHLs with LT $\beta$ R-Ig treatment was markedly reduced (Fig. 7).

\section{DISCUSSION}

$\mathrm{T}$ cell-mediated immune responses play a crucial role in hepatocellular injury induced by autoimmune hepatitis, viral infection, alcohol consumption, and hepatotoxins. ${ }^{9-15)}$ Activated $\mathrm{CD}^{+} \mathrm{T}$ cells are detected infiltrating into the liver and involving in the pathogenesis of a variety of human liver disease. ${ }^{27)} \mathrm{CD} 4^{+} \mathrm{T}$ cells can exert their effects through secretion of pro- and antiinflammatory cytokines. It is high levels of proinflammatory cytokines such as TNF- $\alpha$ and IFN- $\gamma$ contributes to the liver injury. ${ }^{18-21)}$

Several members of the TNF superfamily play important roles in lymphocyte activation, immune regulation, and the development of lymphoid tissues. ${ }^{26-28)}$ Up-regulation of these TNF family members may provide a costimulatory mechanism to increase the proliferation of lymphocytes in an autocrine or paracrine fashion upon stimulation with antigen, and overproduction of some of them can lead to severe chronic inflammation and autoimmune diseases. ${ }^{29-32)}$ There is significant evidence indicating that altered regulation of some TNF family members is linked to autoimmune diseases. $^{33)}$

LIGHT is a member of the TNF superfamily, which is transiently expressed on the surface of activated $\mathrm{T}$ cells and immature dendritic cells. ${ }^{1,2)}$ It was believed to be a potent $\mathrm{T}$ 

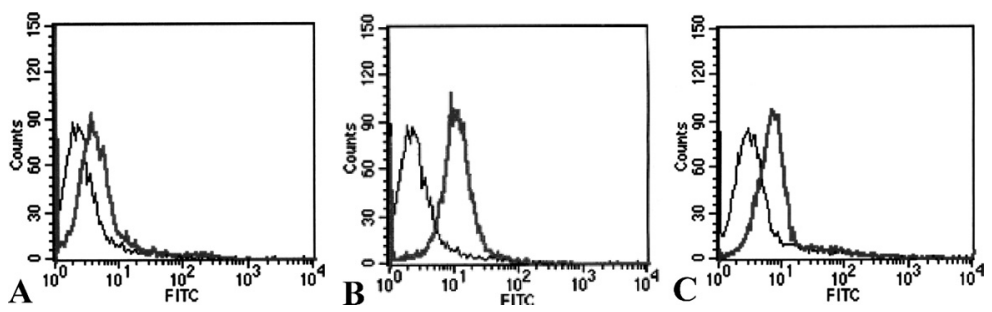

Fig. 7. Representative Image of FACS Analysis on the Level of LIGHT Expression in Isolated Intrahepatic Leukocytes (IHLs) from the Mice of (A) Saline Treatment, (B) ConA + Human IgG Treatment, (C) ConA +LT $\beta$ R-Ig Treatment after $24 \mathrm{~h}$ ConA Injection $(n=10)$

The level of LIGHT expression on the intrahepatic leukocytes with LT $\beta$ R-Ig treatment was markedly reduced, compared with that on those treated with human IgG.

cell costimulatory molecule that appears to interact with the herpesvirus entry mediator (HVEM) expressed on $\mathrm{T}$ cells. $^{1,3,4)}$ Previous studies of $\mathrm{T}$ cells activation have mainly focused on the costimulatory pathway mediated by the interaction of T cells and APCs, such as the CD28/B7 system. Recently many studies suggested that LIGHT played costimulatory activity by its engagement with HVEM, a receptor expressed on T cells: (1) LIGHT involved in T cell proliferation and cytokine production, furthermore can directly costimulate $T$ cell responses ${ }^{1-3,34)}$ (2) Mice expressing the LIGHT transgene on the $\mathrm{T}$ cell lineage exhibited severe $\mathrm{T}$ cell-mediated inflammation and autoimmune diseases. ${ }^{5-7)}$ (3) Blocking LIGHT signaling by HVEM-Ig reduced T cell proliferation and the incidences of $\mathrm{T}$ cell-mediated diseases. ${ }^{7}$

(4) LIGHT $-/-$ mice showed defective $T$ cell responses in vivo and in vitro. ${ }^{35-37)}$ These studies supported the theory that HVEM is a receptor for LIGHT mediated T cell activation.

ConA-induced hepatitis is thought to be a model of immunologically induced hepatocyte injury and experimental studies have demonstrated that ConA induced acute hepatitis in a murine model which shows T-cell infiltration and hepatocyte apoptosis and necrosis in the liver resembles human viral or autoimmune hepatitis. ${ }^{16)}$ T-cell activation which results in the elevation of plasma cytokines, including TNF- $\alpha$, IFN- $\gamma$, IL, plays a crucial role in the process of ConA-induced hepatitis. ${ }^{19)}$ Among those cytokines, TNF- $\alpha$ released from activated $\mathrm{T}$ cells appears to be a prime suspect in causing hepatocyte injury and apoptosis induced by ConA, based on a number of reported observations. TNF- $\alpha$ antiserum or TNF- $\alpha$ inhibitor or mice deficient for TNFR1 and TNFR2 are resistant to ConA-induced hepatitis. ${ }^{17,38,39)}$ IFN- $\gamma$ is also considered to be involved in the development of ConAinduced hepatitis, because mice pretreated with anti-IFN- $\gamma$ antiserum or IFN- $\gamma$-deficient mice are resistant to ConAinduced liver injury. ${ }^{21,40)}$ These studies suggest that overproduction of TNF- $\alpha$ and IFN- $\gamma$ in the liver may participate ConA induced liver injury.

In the present study, we used LT $\beta$ R-Ig to block LIGHT signaling pathway and demonstrated that LT $\beta$ R-Ig protected mice from ConA-induced liver injury and massive liver cell death, effectively lowering ALT and AST characteristic of liver injury (Fig. 1), ameliorating hepatocyte apoptosis and necrosis (Fig. 2). Furthermore, proinflammatory cytokines (TNF- $\alpha$, IFN- $\gamma$ ) in plasma significantly reduced after LT $\beta$ RIg treatment (Fig. 3). In addition, the present study used a murine model of ConA-induced hepatitis, which provided evidence for LIGHT high expression in the hepatic tissue, and decreased expression after the treatment with LT $\beta \mathrm{R}-\mathrm{Ig}$
(Fig. 7), together with LT $\beta$ R-Ig could bind to LIGHT on IHLs as a competitive inhibitor of LIGHT/HVEM pathway (Fig. 6), thus proposing LIGHT/HVEM signaling pathway may be involved in the pathogenesis of ConA induced hepatitis.

In an attempt to elucidate how LT $\beta$ R-Ig exerts its protective effect, we found that there was ConA-induced expansion and infiltration of $\mathrm{CD}^{+} \mathrm{T}$ lymphocyte in the diseased liver and significantly decrease after treatment mice with LT $\beta$ R-Ig (Fig. 4). The direct demonstration that $\mathrm{CD} 4^{+} \mathrm{T}$ lymphocytes are effector cells for ConA-induced liver injury has been well described. ${ }^{16-18)}$ Studies showed that mice pretreated with a T cell-specific immunosuppressive agent failed to develop massive cellular recruitment and hepatic inflammation in response to ConA. ${ }^{16,41)}$ Several evidences have also shown that ConA could directly activate T lymphocytes: 1) proliferate; 2) produce proinflammatory cytokines such as IL-2, TNF- $\alpha$, and IFN- $\gamma$; 3) migrate specifically to the liver within hours of exposure. ${ }^{42,43)}$ ConA-mediated cytokine production depends on the interactions between $\mathrm{CD} 4^{+} \mathrm{T}$ cells and NKT cells. ${ }^{44)}$ Study suggested that early cytokine production in ConA induced hepatitis attributed to $\mathrm{CD} 4^{+}$cells, which include both the NK1.1 $1^{+}$and the NK1.1 $1^{-}$T cell populations. ${ }^{42)}$ So it is plausible that in our study the decreasing plasma levels of TNF- $\alpha$ and IFN- $\gamma$ by LT $\beta$ R-Ig treatment attributed to inhibition infiltration of $\mathrm{CD} 4^{+} \mathrm{T}$ cells.

Finally, we investigated the mechanisms through which LT $\beta$ R-Ig reduced TNF- $\alpha$ and IFN- $\gamma$ production in the liver induced by ConA. One important signaling pathway in the induction of proinflammatory cytokines including TNF- $\alpha$ and IFN- $\gamma$ expression leads to activation of the transcription factor NF- $\kappa \mathrm{B}^{22)}$ Cytokines that are stimulated by NF- $\kappa \mathrm{B}$ can also directly activate the NF- $\kappa \mathrm{B}$ pathway, thus establishing a positive autoregulatory loop that can amplify the inflammatory response. ${ }^{22)}$ Several study demonstrated NF- $\kappa$ B overexpression occurred in response to stimulation by ConA earlier than the increases of proinflammatory cytokines production in ConA induced hepatitis. ${ }^{23)}$ Furthermore, Inhibiting proinflammatory cytokines production through the direct suppressing NF- $\kappa \mathrm{B}$ activation could ameliorate ConA induced hepatitis. ${ }^{23)}$ In the present study, there was induction of NF$\kappa \mathrm{B}$ activation and overexpression responded to ConA stimulation in liver in according to previous study, and markedly decreased after LT $\beta$ R-Ig treatment (Fig. 5). In addition, previous study suggested that activation of LIGHT/HVEM signaling induced marked activation of NF- $\kappa \mathrm{B} .{ }^{24)}$ So we speculate that LT $\beta$ R-Ig blocked NF- $\kappa \mathrm{B}$ activation in lymphocytes, especially $\mathrm{CD}^{+} \mathrm{T}$ cells in the liver (Fig. 4); subsequently, the expression of proinflammatory cytokines including TNF- 
$\alpha$ and IFN- $\gamma$ were inhibited (Fig. 3). Although NF- $\kappa \mathrm{B}$ is an essential survival factor during liver regeneration, ${ }^{45)}$ activation of NF- $\kappa$ B leads to induction of TNF- $\alpha$ which mediated ConA-induced liver apoptosis and exhibits a pro-apoptotic function through transcriptional Fas (CD95) activation in hepatitis, ${ }^{22,46,47)}$ so in this study hepatic cell rescued from apoptosis by LT $\beta$ R-Ig treatment, which inhibited NF- $\kappa \mathrm{B}$ activation.

Taken together, we could get a conclusion from the present study: LIGHT/HVEM signaling pathway may be involved in the pathogenesis of ConA induced hepatitis. LT $\beta$ R-Ig blocked LIGHT/HVEM signaling as a competitive inhibitor of LIGHT/HVM pathway, resulting in both decreased infiltration of $\mathrm{CD}^{+}{ }^{+} \mathrm{T}$ cells and down-regulation NF- $\kappa \mathrm{B}$ activation and expression in the liver, subsequently proinflammatory cytokines were inhibited, and finally mice were protect from ConA induced hepatic injury. Based upon our results, although the mechanism of treatment with LT $\beta$ R-Ig in ConA induced hepatitis awaits further study, we envision that it maybe also efficacious in patients with autoimmune hepatitis and blocking LIGHT/HVEM signaling would prove to be a promising strategy for human autoimmune hepatitis.

\section{REFERENCES}

1) Mauri D. N., Ebner R., Montgomery R. I., Kochel K. D., Cheung T. C., Yu G. L., Ruben S., Murphy M., Eisenberg R. J., Cohen G. H., Spear P. G., Ware C. F., Immunity, 8, 21-30 (1998).

2) Zhai Y., Guo R., Hsu T. L., Yu G. L., Ni J., Kwon B. S., Jiang G. W., Lu J., Tan J., Ugustus M., Carter K., Rojas L., Zhu F., Lincoln C., Endress G., Xing L., Wang S., Oh K. O., Gentz R., Ruben S., Lippman M. E., Hsieh S. L., Yang D., J. Clin. Invest., 102, 1142-1151 (1998).

3) Tamada K., Shimozaki K., Chapoval A. I., Zhu G., Sica G., Flies D., Boone T., Hsu H., Fu Y. X., Nagata S., Ni J., Chen L., Nat. Med., 6, $283-289$ (2000).

4) Rooney I. A., Butrovich K. D., Glass A. A., Borboroglu S., Benedict C. A., Whitbeck J. C., Cohen G. H., Eisenberg R. J., Ware C. F., J. Biol. Chem., 275, 14307-14315 (2000).

5) Shaikh R. B., Santee S., Granger S. W., Butrovich K., Cheung T., Kronenberg M., Cheroutre H., Ware C. F., J. Immunol., 167, 6330-6337 (2001).

6) Wang J., Lo J. C., Foster A., Yu P., Chen H. M., Wang Y., Tamada K., Chen L., Fu Y. X., J. Clin. Invest., 108, 1771-1780 (2001).

7) Wang J., Anders R. A., Wu Q., Peng D., Cho J. H., Sun Y., Karaliukas R., Kang H. S., Turner J. R., Fu Y. X., J. Clin. Invest., 113, 826-835 (2004).

8) An M. M., Fan K. X., Zhang J. D., Li H. J., Song S. C., Liu B. G., Gao P. H., Zhou Q., Jiang Y. Y., Pharmacol. Res., 52, 234-244 (2005).

9) Kita H., Mackay I. R., Van De Water J., Gershwin M. E., Gastroenterology, 120, 1485-1501 (2001).

10) Heneghan M. A., McFarlane I. G., Hepatology, 35, 7-13 (2002).

11) Bogdanos D. P., Mieli-Vergani G., Vergani D., Dig. Liver. Dis., 32, $440-446$ (2000)

12) Lohr H. F., Schlaak J. F., Lohse A. W., Bocher W. O., Arenz M., Gerken G., Meyer Z., Buschenfelde K. H., Hepatology, 24, 1416 1421 (1996).

13) Rosen H. R., Miner C., Sasaki A. W., Lewinsohn D. M., Conrad A. J., Bakke A., Bouwer H. G., Hinrichs D. J., Hepatology, 35, 190-198 (2002).

14) Chang K. M., Thimme R., Melpolder J. J., Oldach D., Pemberton J., Moorhead-Loudis J., McHutchison J. G., Alter H. J., Chisari F. V., Hepatology, 33, 267-276 (2001).

15) Chedid A., Mendenhall C. L., Moritz T. E., French S. W., Chen T. S., Morgan T. R., Roselle G. A., Nemchausky B. A., Tamburro C. H., Schiff E. R., Gastroenterology, 105, 254-266 (1993).

16) Tiegs G., Hentschel J., Wendel A., J. Clin. Invest., 90, 196-203 (1992).
17) Mizuhara H., O’Neill E., Seki N., Ogawa T., Kusunoki C., Otsuka K., Satoh S., Niwa M., Senoh H., Fujiwara H., J. Exp. Med., 179, 15291537 (1994).

18) Gantner F., Leist M., Lohse A. W., Germann P. G., Tiegs G., Hepatology, 21, 190-198 (1995).

19) Watanabe Y., Morita M., Akaike T., Hepatology, 24, 702-710 (1996).

20) Mizuhara H., Uno M., Seki N., Yamashita M., Yamaoka M., Ogawa T., Kaneda K., Fujii T., Senoh H., Fujiwara H., Hepatology, 23, 1608 1615 (1996).

21) Kusters S., Gantner F., Kunstle G., Tiegs G., Gastroenterology, 11, 462-471 (1996).

22) Yamamoto Y., Gaynor R. B., J. Clin. Invest., 107, 135-142 (2001)

23) Imose M., Nagaki M., Kimura K., Takai S., Imao M., Naiki T., Osawa Y., Asano T., Hayashi H., Moriwaki H., Hepatology, 40, 1160-1169 (2004).

24) Marsters S. A., Ayres T. M., Skubatch M., Gray C. L., Rothe M., Ashkenazi A., J. Biol. Chem., 272, 14029-14032 (1997).

25) Essani N. A., Bajt M. L., Farhood A., Vonderfecht S. L., Jaeschke H., J. Immunol., 158, 5941-5948 (1997).

26) Ettinger R., Curr. Top. Microbiol. Immunol., 251, $203-210$ (2000).

27) Locksley R. M., Killeen N., Lenardo M. J., Cell, 104, 487-501 (2001).

28) Wang Y., Wang J., Sun Y., Wu Q., Fu Y. X., J. Immunol., 166, 330337 (2001).

29) Banchereau J., Bazan F., Blanchard D., Briere F., Galizzi J. P., van Kooten C., Liu Y. J., Rousset F., Saeland S., Annu. Rev. Immunol., 12, $881-922$ (1994).

30) Kwon B., Moon C. H., Kang S., Seo S. K., Kwon B. S., Mol. Cells, 10, $119-126(2000)$

31) Schneider P., MacKay F., Steiner V., Hofmann K., Bodmer J. L., Holler N., Ambrose C., Lawton P., Bixler S., Acha-Orbea H., Valmori D. Romero P., Werner-Favre C., Zubler R. H., Browning J. L., Tschopp J., J. Exp. Med., 189, 1747-1756 (1999).

32) Shu H. B., Hu W. H., Johnson H., J. Leukoc. Biol., 65, 680-683 (1999).

33) Mackay F., Kalled S. L., Curr. Opin. Immunol., 14, 783-790 (2002).

34) Tamada K., Shimozaki K., Chapoval A. I., Zhai Y., Su J., Chen S. F., Hsieh S. L., Nagata S., Ni J., Chen L., J. Immunol., 164, 4105-4110 (2000).

35) Ye Q., Fraser C. C., Gao W., Wang L., Busfield S. J., Wang C., Qiu Y., Coyle A. J., Gutierrez-Ramos J. C., Hancock W. W., J. Exp. Med., 195, 795-800 (2002)

36) Scheu S., Alferink J., Potzel T., Barchet W., Kalinke U., Pfeffer K., J. Exp. Med., 195, 1613-1624 (2002).

37) Tamada K., Ni J., Zhu G., Fiscella M., Teng B., van Deursen J. M., Chen L., J. Immunol., 168, 4832- 4835 (2002).

38) Ksontini R., Colagiovanni D. B., Josephs M. D., Edwards C. K. III, Tannahill C. L., Solorzano C. C., Norman J., Denham W., Clare-Salzler M., MacKay S. L., Moldawer L. L., J. Immunol., 160, 4082-4089 (1998).

39) Kusters S., Tiegs G., Alexopoulou L., Pasparakis M., Douni E., Kunstle G., Bluethmann H., Wendel A., Pfizenmaier K., Kollias G., Grell M., Eur. J. Immunol., 27, 2870-2875 (1997).

40) Tagawa Y., Sekikawa K., Iwakura Y., J. Immunol., 159, 1418-1428 (1997).

41) Wang Y., Subudhi S. K., Anders R. A., Lo J., Sun Y., Blink S., Wang Y., Wang J., Liu X., Mink K., Degrandi D., Pfeffer K., Fu Y. X., J. Clin. Invest., 115, 711-717 (2005)

42) Lis H., Sharon N., Annu. Rev. Biochem., 55, 35-67 (1986).

43) Hokari R., Miura S., Fujimori H., Koseki S., Tsuzuki Y., Kimura H., Higuchi H., Serizawa H., Granger D. N., Ishii H. A., Am. J. Physiol., 277, G763-772 (1999).

44) Sun R., Tian Z., Kulkarni S., Gao B., J. Immunol., 172, 5648-5655 (2004).

45) Iimuro Y., Nishiura T., Hellerbrand C., Behrns K. E., Schoonhoven R., Grisham J. W., Brenner D. A., J. Clin. Invest., 101, 802-811 (1998).

46) Mizuhara H., O’Neill E., Seki N., Ogawa T., Kusunoki C., Otsuka K., Satoh S., Niwa M., Senoh H., Fujiwara H., J. Exp. Med., 179, 15291537 (1994).

47) Kuhnel F., Zender L., Paul Y., Tietze M. K., Trautwein C., Manns M., Kubicka S., J. Biol. Chem., 275, 6421-6427 (2000). 